\title{
Listerial contamination of raw beef and chevon in north-central Nigeria
}

\author{
Aleruchi Chuku, Godwin Attah Obande and Sani Bashir Eya \\ Department of Microbiology, Faculty of Science, Federal University Lafia, Nasarawa state, Nigeria
}

\begin{abstract}
Background and objective: Listeria sp. is a ubiquitous and frequently isolated foodborne pathogen. The prevalence of Listeria sp in raw beef and chevon sold in Lafia Nigeria, as well as their antibiotic susceptibility profile was evaluated.
\end{abstract}

Methods: A total 104 samples comprising of 52 raw beef and 52 chevon were obtained from street vendors (hawkers), Shinge abattoir, Lafia old market and Lafia Modern Market. Isolation of Listeria sp. was performed on Listeria Selective Agar, following enrichment in supplemented Listeria Selective Broth. Identification of Listeria sp. was carried out by cultural and biochemical methods. Antimicrobial susceptibility of isolated L. monocytogenes was performed by standard disk diffusion method. Chi-square test was used to determine association between contamination levels at $p=0.05$.

Results: Seven types of Listeria sp. were isolated. L. monocytogenes and L. ivanovii were the most frequently isolated contaminants in all meat types and from all sample sources. $L$. monocytogenes was isolated with a frequency of $64.4 \%$ (67/104) in the meat samples. Beef samples had the highest listerial contamination with a frequency of 58.2\% (78/134) compared to chevon which had a listerial frequency of $41.8 \%$ (56/134). Resistance of $L$. monocytogenes to streptomycin and sparfloxacin was $58.2 \%$ and $55.2 \%$ respectively. Resistance to ampicillin $(34.3 \%)$ and gentamicin $(20.9 \%)$ was also observed. Resistances to multiple antimicrobials were detected in $11 \mathrm{~L}$. monocytogenes isolates.

Conclusion: The study demonstrated that the raw meat sold in Lafia was contaminated with several Listeria sp. L. monocytogenes showed high rate of resistance to several antimicrobial agents used for the treatment of listerial infection. Appropriate regulation and monitoring of livestock rearing and meat retailing practices are advocated to safeguard the health of consumers.

IMC J Med Sci 2019; 13(2): 001. EPub date: 18 July 2019

\section{Introduction}

Listeria monocytogenes is a facultative anaerobic bacterium which can grow and reproduce inside the host's cells, making it one of the most virulent food-borne pathogens. Unlike most other foodborne pathogens it can grow and multiply at a very low temperatures [1,2]. L. monocytogenes has been typed into four serotypes of which only three $(1 / 2 a, 1 / 2 b, 4 b)$ are involved in $95 \%$ of all human listeriosis cases [3].
It belongs to the genus Listeria which is widely distributed in the environment. The genus currently includes a total of seven species namely $L$. monocytogenes, L. ivanovii, L. innocua, L. seeligeri, L. murrayi, L. grayi and L. welshimeri [4]. Of these species, $L$. monocytogenes and $L$. ivanovi are the only species found to be pathogenic to humans and other animals [5].

L. monocytogenes is a constant challenge for the food industry, health regulatory officials and 
consumers [6] since it remains as one of the most virulent foodborne pathogens for immunodeficient individuals. It has been extensively studied over the past few decades due to its high case/fatality rate (20-30\%), chronic infection resulting in high healthcare cost and its ability to survive for longer periods under adverse environmental conditions than many other non-spore-forming bacteria [7].

In man, outbreaks usually occur following consumption of unpasteurized milk, contaminated cheeses and other dairy products. Reports of outbreaks have also followed ingestion of undercooked meat and poultry [8]. It is frequently present in the gut of cattle, poultry and pigs and can be transmitted through ready-to-eat (RTE) foods or raw meat products [9]. Listeria species are isolated from a diversity of environmental sources, including decaying vegetation, soil, water, effluents, variety of foods, and the faeces of humans and animals [10].

L. monocytogenes is a major contaminant of RTE food and food products. Packaged raw foods can represent a potential source of contamination, and listeriosis is associated with the consumption of such undercooked raw foods [11]. Major changes in food production, processing and distribution, increased use of refrigeration as a primary preservation method, changes in eating habits particularly towards ready-to-eat foods are suggested as possible reasons for the emergence of human food-borne listeriosis [12].

While several studies have reported antibiotic resistance in bacterial isolates from human beings, it is becoming evident that food produced from farm animals is no longer exempted from antibiotic resistant bacteria [13]. Thus, the food microflora is not separated from its human counterpart in cases of antibiotic resistance. The occurrence of infection by antibiotic resistant organisms makes treatment difficult and increases the period of recovery from illness [14]. This situation has been worsened by the indiscriminate use of common broad spectrum antibiotics as prophylaxis and growth promoters in animal feed, particularly in developing nations $[14,15]$.

There has been a dearth of information on the epidemiology of listeriosis in most African countries, including Nigeria [16] with only few reports, when compared to other developed regions like Europe and United States of America [17]. This is because the organism seems not to have been given as much attention as is required $[18,19]$. Listeriosis is considered a serious health problem due to its high mortality rate and severity of symptoms. Despite the foregoing and the continuous observation of the emergence of antibiotic resistant strains of Listeria, there is little or no documented reports of its prevalence and its antibiotic susceptibility profile in Lafia of Nasarawa state of Nigeria.

\section{Methods}

Study area and period: This study was conducted in Lafia, Nasarawa state which lies between latitude $8^{\circ} 25^{\prime} 40^{\prime \prime} \mathrm{N}$ to $8^{\circ} 34^{\prime} 15^{\prime \prime} \mathrm{N}$ and longitude $8^{\circ} 24^{\prime} 25^{\prime \prime} \mathrm{E}$ to $8^{\circ} 38^{\prime} 19^{\prime \prime} \mathrm{E}$ in the guinea savannah region of North-Central Nigeria. Lafia is a large town in Nasarawa state with an estimated population of 330, 712 [20]. The study was carried out from June to August which witnessed increased slaughtering of animals in commemoration of the Eid il-Fitr celebration in the month of July, 2016.

Sample collection: Preliminary investigation identified the Shinge abattoir, open markets (Lafia old market and Modern market) and hawkers as major sources of retail fresh raw meat within Lafia. A total of 104 samples comprising of 52 raw beef samples and 52 raw chevon samples were collected randomly from the four identified sources in the morning hours to prevent effects of changing temperatures on microbial population. The meat samples were bought and packaged as they are sold to other consumers, appropriately labeled and transported within 90 minutes to the laboratory for analysis. Contamination of the meat samples by other materials or sources such as collector's hand was avoided.

Isolation of Listeria sp: Isolation of Listeria from the meat samples were based on the method described by Ndahi et al. [21] and Adikwu et al. [19] with some modifications. Aseptically, $10 \mathrm{~g}$ of each sample was added to $90 \mathrm{ml}$ Listeria Enrichment broth (Oxoid, Basingstoke, UK) containing Listeria Selective Enrichment Supplement. The mixture was homogenized for 2 minutes in a blender 
(MasterChef) at room temperature and incubated at $30^{\circ} \mathrm{C}$ for 24 hours. Listeria species were isolated on Listeria Selective Agar (Oxoid) using pour plate method, by transferring $1 \mathrm{ml}$ of the overnight supplement culture into molten Listeria Selective agar and incubating for 48 hours at $37^{\circ} \mathrm{C}$, after which the plates were examined for the presence of listeria-like growths.

Identification of Listeria sp: Listeria was identified by standard methods as previously described $[22,23]$. Suspected colonies were identified by Gram stain, motility, catalase reaction, haemolysin production, indole, urease, CAMP (Christie, Atkins, and Munch-Peterson) and sugar fermentation (rhamnose, mannose, xylose and mannitol) tests.

Antimicrobial susceptibility test: Antibiotic susceptibility of the isolated L. monocytogenes was determined by the Kirby-Bauer disk diffusion method on Mueller-Hinton Agar [19,25]. The antibiotics used include erythromycin $(15 \mu \mathrm{g})$, streptomycin $(10 \mu \mathrm{g})$, co-trimoxazole $(1.25 / 23.75 \mu \mathrm{g})$, rifampicin $(5 \mu \mathrm{g})$, nalidixic acid $(30 \mu \mathrm{g})$, ciprofloxacin $(5 \mu \mathrm{g})$, ampicillin $(10 \mu \mathrm{g})$, gentamicin $(10 \mu \mathrm{g})$, chloramphenicol $(30 \mu \mathrm{g})$, sparfloxacin $(5 \mu \mathrm{g})$ and ofloxacin $(5 \mu \mathrm{g})$. A broth culture of at least 18 hours old was diluted using sterile distilled water and standardized to match $0.5 \mathrm{McFarland}$ standards (approximately $10^{8} \mathrm{cfu} / \mathrm{ml}$ ). The culture was inoculated onto dried Mueller-Hinton Agar (MHA, Oxoid) plate to create a lawn. Antibiotic discs were then placed on the seeded agar surfaces and the plates incubated for 24 hours at $37^{\circ} \mathrm{C}$, after which the diameter (in $\mathrm{mm}$ ) of the inhibition zone around each disk was measured and interpreted according to the Clinical Laboratory Standard Institute (CLSI) guidelines using the break points of Staphylococcus species [25].

Statistical analysis: IBM SPSS Statistics version 22.0 (IBM Corp., Armonk, NY, USA; 2013) was used to analyse results obtained. Pearson's chi-square test was used to determine significance of associations between variables. A $p$-value less than 0.05 was considered statistically significant.

\section{Results}

The prevalence of Listeria species isolated from 104 samples is shown in Table-1. L. monocytogenes had the highest prevalence rate of $64.4 \%(67 / 104)$ while $L$. grayi had the lowest rate of $2.9 \%(3 / 104)$. L. ivanovii was isolated from $21.2 \%$ samples. Mixed contamination with more than one species was observed in some samples. L. monocytogenes was isolated from $42(80.8 \%)$ and $25(48.1 \%)$ of beef and chevon samples respectively. Differences in $L$. monocytogenes contamination was statistically significant $(p<0.01)$. Beef samples had the highest listerial presence of $58.2 \%(78 / 134)$ against $41.8 \%$ $(56 / 134)$ in chevon samples.

Table-2 shows the distribution of Listeria spp isolated from raw beef samples collected from different locations. L. monocytogenes was most frequently isolated in sample sources, having a frequency of $76.9 \%(10 / 13)$ in both Shinge abattoir and Street hawker samples, and $86.4 \%(11 / 13)$ in samples from Lafia old market and Lafia modern market. The second most isolated species from Shinge abattoir and Street hawker samples was $L$.

Table-1: Types of Listeria species isolated from beef $(n=52)$ and chevon samples ( $n=52)$

\begin{tabular}{|c|c|c|c|}
\hline \multirow[t]{2}{*}{ Listeria species } & \multicolumn{2}{|c|}{ Meat } & \multirow{2}{*}{$\begin{array}{l}\text { Total } \\
\text { n (\%) }\end{array}$} \\
\hline & $\begin{array}{l}\text { Beef } \\
\mathrm{n}(\%)\end{array}$ & $\begin{array}{c}\text { Chevon } \\
\mathrm{n}(\%)\end{array}$ & \\
\hline L. monocytogenes* & $42(80.8)$ & 25 (48.1) & $67(64.4)$ \\
\hline L. ivanovii & $12(23.1)$ & $10(19.2)$ & $22(21.2)$ \\
\hline L. innocua & $10(19.2)$ & $10(19.2)$ & 20 (19.2) \\
\hline L. seeligeri & $3(5.8)$ & $6(11.5)$ & $9(8.7)$ \\
\hline L. welshimeri & $4(7.7)$ & $2(3.9)$ & $6(5.8)$ \\
\hline L. grayi & $2(3.9)$ & 1 (1.9) & $3(2.9)$ \\
\hline L. murrayi & $5(9.6)$ & $2(3.9)$ & $7(6.7)$ \\
\hline Total & 78 (58.2) & $56(41.8)$ & $134(100)$ \\
\hline
\end{tabular}

Note: Some samples yielded more than one species; ${ }^{*} p<0.005$ 
Table-2: Distribution of Listeria species in raw beef samples collected from different locations

\begin{tabular}{|c|c|c|c|c|}
\hline \multirow[t]{2}{*}{ Listeria species } & \multicolumn{4}{|c|}{ Beef samples collected from } \\
\hline & $\begin{array}{l}\text { Shinge } \\
\text { (n=13) } \\
n(\%)\end{array}$ & $\begin{array}{l}\text { Lafia old market } \\
\qquad(n=13) \\
n(\%)\end{array}$ & $\begin{array}{l}\text { Lafia modern market } \\
\qquad \begin{array}{c}(n=13) \\
n(\%)\end{array}\end{array}$ & $\begin{array}{c}\text { Street hawkers } \\
(\mathrm{n}=13) \\
\mathrm{n}(\%)\end{array}$ \\
\hline L. monocytogenes* & $10(76.9)$ & $11(84.6)$ & $10(76.9)$ & $11(84.6)$ \\
\hline L. ivanovii & $5(38.5)$ & $1(7.7)$ & $2(15.4)$ & $4(30.8)$ \\
\hline L. innocua & $3(23.1)$ & $3(23.1)$ & $3(23.1)$ & $1(7.7)$ \\
\hline L. seeligeri & $1(7.7)$ & $1(7.7)$ & $0(0)$ & $1(7.7)$ \\
\hline L. welshimeri & $1(7.7)$ & $1(7.7)$ & $1(7.7)$ & $1(7.7)$ \\
\hline L. grayi & $0(0)$ & $0(0)$ & $1(7.7)$ & $1(7.7)$ \\
\hline L. murrayi & $2(15.4)$ & $1(7.7)$ & $2(15.4)$ & $0(0)$ \\
\hline Total $(n=78)$ & $22(28.2)$ & $18(23.1)$ & $19(24.4)$ & $19(24.4)$ \\
\hline
\end{tabular}

Note: *Differences not statistically significant ( $p>0.05)$. Some samples yielded more than one species

ivanovii with frequencies of $38.5 \%(5 / 13)$ and $30.8 \%$ (4/13) respectively. L. inocua were the second most isolated species in both Lafia old market and Lafia modern market with frequencies of $23.1 \%(3 / 13)$ respectively. At most, only one Listeria spp type was absent from each sample source. L. monocytogenes, $L$. ivanovii and $L$. innocua were isolated from all the collection sites. Beef samples from Shinge abattoir had the highest number of listeria contaminants (28.2\%; 22/78), followed by Lafia modern market and street vendors which had the same number of listeria contaminants $(24.4 \%$; 19/78). Lafia old market had the least number of listeria contaminants $(23.1 \%$; 18/78). Contamination rate in the respective sources were however, not different statistically $(p>0.05)$.

Table- 3 shows the distribution of Listeria species in raw chevon samples from the different sample sources. Samples from Shinge abattoir had the highest number of listerial contaminants $(51.8 \%$; 29/56) while Lafia old market had the least (48.2\%; 27/56). L. monocytogenes was most prevalent in both sources (46.2\%; $12 / 26$ and $50.0 \%$; $13 / 26$ respectively). No $L$. grayi was found in samples obtained from Shinge abattoir. L. welshimeri, $L$. grayi and L. murrayi were the least occurring species in samples from Lafia old market with a frequency of $3.8 \%(1 / 26)$ respectively. Differences in contamination rates were not statistically significant $(p>0.05)$.
Table-3: Distribution of Listeria species in raw chevon samples collected from Shinge and Lafia old market

\begin{tabular}{|c|c|c|}
\hline \multirow[t]{2}{*}{ Listeria species } & \multicolumn{2}{|c|}{$\begin{array}{c}\text { Chevon samples } \\
\text { collected from }\end{array}$} \\
\hline & $\begin{array}{c}\text { Shinge } \\
\text { (n=26) } \\
n(\%)\end{array}$ & $\begin{array}{c}\text { Lafia old } \\
\text { market } \\
(n=26) \\
n(\%)\end{array}$ \\
\hline L. monocytogenes* & $12(46.2)$ & $13(50.0)$ \\
\hline L. ivanovii & 7 (26.9) & $3(11.5)$ \\
\hline L. innocua & $5(19.2)$ & 5 (19.2) \\
\hline L. seeligeri & $3(11.5)$ & $3(11.5)$ \\
\hline L. welshimeri & $1(3.8)$ & $1(3.8)$ \\
\hline L. grayi & $0(0)$ & $1(3.8)$ \\
\hline L. murrayi & $1(3.8)$ & $1(3.8)$ \\
\hline Total $(n=56)$ & $29(51.8)$ & $27(48.2)$ \\
\hline
\end{tabular}

Note: *Differences not statistically significant. Some samples yielded more than one species

A total 67 L. monocytogenes isolates were tested for susceptibility to different antimicrobial agents. Resistance to nalidixic acid, co-trimoxazole and sparfloxacin was $100 \%, 58.2 \%$ and $55.2 \%$ respectively (Table-4). Susceptibility rate of $76.1 \%$, $65.7 \%, 61.2 \%$ and $55.2 \%$ was observed with rifampicin, ampicillin, gentamicin and erythromycin respectively. Eleven $L$. monocytogenes strains showed resistance to more than one antibiotic. 
Table-4: Susceptibility pattern of L. monocytogenes to selected antimicrobial agents $(N=67)$

\begin{tabular}{lccc}
\hline ANTIBIOTICS & $\begin{array}{c}\text { Susceptible } \\
\mathbf{n}(\%)\end{array}$ & $\begin{array}{c}\text { Intermediate } \\
\mathbf{n}(\%)\end{array}$ & $\begin{array}{c}\text { Resistant } \\
\mathbf{n}(\%)\end{array}$ \\
\hline Streptomycin & $9(13.4)$ & $19(28.4)$ & $39(58.2)$ \\
Co-trimoxazole & $23(34.3)$ & $10(14.9)$ & $34(50.8)$ \\
Chloramphenicol & $23(34.3)$ & $12(17.9)$ & $32(47.8)$ \\
Sparfloxacin & $22(32.8)$ & $14(20.9)$ & $37(55.2)$ \\
Ciprofloxacin & $30(44.8)$ & $26(38.8)$ & $11(16.4)$ \\
Ampicillin & $44(65.7)$ & $0(0)$ & $23(34.3)$ \\
Gentamycin & $41(61.1)$ & $12(17.9)$ & $14(20.9)$ \\
Ofloxacin & $30(44.8)$ & $6(9.0)$ & $31(46.3)$ \\
Rifampicin & $51(76.1)$ & $5(7.5)$ & $11(16.4)$ \\
Erythromycin & $37(55.2)$ & $14(20.9)$ & $16(23.9)$ \\
Nalidixic acid & $0(0)$ & $0(0)$ & $67(100)$ \\
\hline
\end{tabular}

\section{Discussion}

Results of this study revealed a high prevalence of L. monocytogenes in raw beef and chevon sold in Lafia. The prevalence rate of Listeria species observed in this study was lower than the $95.8 \%$ prevalence rate reported in vegetable salads in Zaria, Kaduna state [24] but higher than the 39.6\% and $7.8 \%$ observed in Sokoto [26] and in Makurdi, Benue state [19]. The high L. monocytogenes contamination observed in the raw meat samples was in concordance with an earlier report where 14 out of the 15 Listeria species isolated were $L$. monocytogenes [27]. Similarly, the high prevalence of $L$. monocytogenes in beef samples confirms an earlier report [17].

The present study appears to be the first investigation regarding presence of Listeria $\mathrm{sp}$ in retailed meat within Nasarawa state. The high prevalence of Listeria in the two widely consumed meats raises an issue of serious public health importance. It is possible that cases of listeriosis may have been misdiagnosed across health centers in the study area since they do not include investigations for listeria infection in clinical specimens. Some of the symptoms associated with the disease onset such as gastroenteritis, headache, fatigue, muscular and joint pain are similar to those of typhoid fever [28]. Moreover, not much appears to be known about this organism in Nigeria and most African countries [16].

The least common listeria isolate was $L$. grayi while the most observed was $L$. monocytogenes. This was in contrast with an earlier report [26] where $L$. seeligeri and $L$. innocua were the least and the most observed listerial contaminants respectively. Listerial contamination of beef was highest in samples from the Shinge abattoir. Contamination was higher in beef than chevon, an observation that was also reported by earlier studies $[22,29]$. Although not determined in this study, the difference in contamination between the two meat types might have been influenced by factors such as $\mathrm{pH}$ and water activity $\left(\mathrm{a}_{\mathrm{w}}\right)$. For instance, $L$. monocytogenes is known to survive at a $\mathrm{pH}$ of $<4.3$ and water activity of $<0.930$ [30]. The high rate of Listeria contaminants identified in beef samples from this source could be due to unhygienic practices such as slaughtering and preparing of meat on bare floor, poor drainage system, use of contaminated water, poor facility maintenance, illiteracy and lack of hygiene awareness by the handlers, as well as improper storage facilities. Vending of these meats is mostly done without any covering, thus exposing the meats to high rate of microbial contamination. Adoption of proper methods during slaughtering of animals have been suggested as a means of considerably reducing presence of listeria in meats [31,32].

Chevon samples from Lafia old market had less listerial contaminants than those from Shinge abattoir. This could be due to double-washing process practiced in Lafia old market; the meats are washed after slaughtering and before sales to butchers (retailers), unlike at Shinge abattoir where this is not practiced. The practice of repeated 
washing might have enhanced the removal of surface contaminants from the meat obtained from Lafia old market.

Findings also showed that the isolated $L$. monocytogenes was either sensitive or intermediate sensitive to most of the antimicrobial agents tested. Susceptibility to some antibiotics and the multiple antimicrobial resistance observed in this study is similar to earlier reports $[19,21,24]$. Almost all the studied strains were susceptible to a wide range of antibiotics but completely resistant to nalidixic acid. This observation is in agreement with the earlier reports $[33,34]$. Resistance to nalidixic acid justifies addition of nalidixic acid into selective media for the isolation of $L$. monocytogenes. Susceptibility to ampicillin, erythromycin, chloramphenicol, co-trimoxazole and gentamicin, observed in this study is similar to that reported by Troxiler et al. [35] and Hansen et al. [36]. Listeriosis is treated usually with $\beta$-lactam antibiotics like ampicillin or penicillin alone, or combined with an aminoglycoside (usually gentamicin) [37]. However, about 20-34\% of the isolated L. monocytogenes were resistant to ampicillin, gentamicin and erythromycin in this study. This portends a serious public health issue. Around Lafia, meat is prepared by roasting, apart from boiling and frying; sometimes, this may not be enough to destroy deep listerial contaminants, leaving consumers of such products at risk of foodborne diseases.

The resistance pattern observed in the present study could be attributed to the irrational use of the antibiotics in cattle and goat by the animal rearers or veterinary quacks [26]. Misuse of antibiotics as growth promoters can confer selective pressure on bacteria [38], making those increasingly resistant to conventional antibiotics. Although not determined experimentally, horizontal gene transfer among bacteria in the environment could also been responsible for antibiotic resistance as observed in this study $[38,39]$.

\section{Conclusion}

Listeria contamination of raw beef and chevon sold in Lafia is alarming. Unhygienic practices amongst meat handlers at the collection site could be the major source of contamination. Use of contaminated water, washing without addition of disinfectant, lack of awareness, improper storage facilities, poor equipment maintenance and dirty environment were factors believed to be the major causes and sources of listerial contamination observed in this study.

\section{Authors' contributions}

GAO conceived the idea of the study. AC, GAO and SBE designed the study. SBE and GAO conducted the study. GAO performed statistical analysis of data. AC, SBE and GAO wrote, reviewed and approved the final manuscript.

\section{Conflict of interest}

The authors hereby, declare that no conflict of interest exists.

\section{References}

1. Huss, HH, Reilly A, Embarek PKB. Prevention and control of hazards in seafood. Food Control. 2000; 11(2): 149-56.

2. Jeyaletchumi $P$, Tunung R, Margaret $S P$, Son R, Farinazleen MG, Cheah YK. Review article: Detection of Listeria monocytogenes in foods. Int Food Res J. 2010; 17: 1-11.

3. Wang $W$, Zhou $X$, Suo $Y$, Deng $X$, Cheng $M$, Shi $C$, Shi $X$. Prevalence, serotype diversity, biofilm-forming ability and eradication of Listeria monocytogenes isolated from diverse foods in Shanghai, China. Food Control. 2017; 73B: 1068-1073.

4. Gebretsadik S, Kassa T, Alemayehu H, Huruy K, Kebede $\mathrm{N}$. Isolation and characterization of Listeria monocytogenes and other Listeria species in foods of animal origin in Addis Abada, Ethiopia. J Infect Public Health. 2011; 4(1): 22- 29.

5. Robinson RK, Batt CA, Patel PD. (eds). Encyclopedia of Food Microbiology. San Diego, CA: Academic Press; 2000. 
6. Selby, TL, Berzins A, Gerrard DE, Corvalan CM, Grant AL, Linton RH. Microbial heat resistance of Listeria monocytogenes and the impact on ready-to-eat meat quality after post-package pasteurization. Meat Science. 2006; 74(3): 425-34.

7. Fenlon DR. Listeria monocytogenes in the natural environment. In: Ryser ET, Marth EH, editors. Listeria, Listeriosis and food safety. New York: Marcel Dekker; 1999. pp. 21-37.

8. Ryser ET, Arimi SM, Bunduki MM, Donnelly CW. Recovery of different Listeria ribotypes from naturally contaminated, raw refrigerated meat and poultry products with two primary enrichment media. Appl Environ Microbiol. 1996; 62: 1781-7.

9. Jones $A D$, Seeliger HPR. The Genus Listeria. In: Balows A, Trüper HG, Dworkin M, Harder W, Schleifer $\mathrm{KH}$, editors. Prokaryotes: a handbook on the biology of bacteria: Ecophysiology, isolation, identification, applications. 2nd Ed. New York, NY: Springer Verlag; 1992. pp. 1595 1616.

10. Kuhn M, Goebel W. Molecular virulence determinants of Listeria monocytogenes. In: Ryser ET, Marth EH, editors. Listeria, listeriosis and food safety. Boca Raton: CRC Press Taylor and Francis Group; 2007. pp. 111-155.

11. Centers for Disease Control and Prevention (CDC). National Listeria Surveillance Annual Summary, 2008. Atlanta, Georgia: US Department of Health and Human Services, CDC, 2011.

12. Chodorowska M, Kuklinska D. Virulence factors of Listeria monocytogenes and pathogenesis, clinical symptoms and antibiotic therapy of listeriosis. Post Mikrobiol. 2002; 41: 37-49.

13. Teuber M. Spread of antibiotic resistance with food borne pathogens. Cell Mol Life Sci. 1999; 56(9-10): 755-63.

14. Harakeh S, Saleh I, Zouhairi O, Baydoun E, Barbour E, Alwan N. Antimicrobial resistance of Listeria monocytogenes isolated from dairybased food products. Sci Total Environ. 2009; 407(13): 4022-7.

15. Bondarianzadeh D. Food risk to babies listeriosis. Nutrition Today. 2007; 42: 236-9.
16. Enurah LU, Aboaba OO, Nwachukwu SCU, Nwosuh Cl. Antibiotic resistant profiles of food (fresh raw milk) and environmental (abattoir effluents) isolates of Listeria monocytogenes from the six zones of Nigeria. Afr J Microbiol Res. 2013; 7(34): 4373-8.

17. Molla B, Yilma R, Alemayehu D. Listeria monocytogenes and other Listeria species in retail meat and milk products in Addis Ababa, Ethiopia. Ethiop J Health Dev. 2004; 18(3): 131212.

18. Ishola OO, Mosugu JI, Adesokan HK. Prevalence and antibiotic susceptibility profiles of Listeria monocytogenes contamination of chicken flocks and meat in Oyo State, south-western Nigeria: Public health implications. J Prev Med Hyg. 2016; 57(3): E157-E163.

19. Adikwu Peter, E.U. Umeh, E.T. Azua and Godwin Attah Obande. Prevalence and Antimicrobial Susceptibility of Listeria monocytogenes Isolated from Beef, Pork and Chicken Sold in Makurdi Metropolis. $\mathrm{Br}$ Microbiol Res J. 2016; 14(5): 1-7.

20. National Population Commission. Federal Republic of Nigeria Official Gazette Number 2. Volume 96, $2^{\text {nd }}$ February 2009.

21. Ndahi MD, Kwaga JKP, Bello M, Kabir J, Umoh VJ, Yakubu SE, Nok AJ. Prevalence and antimicrobial susceptibility of Listeria monocytogenes and methicillin-resistant Staphylococcus aureus strains from raw meat and meat products in Zaria, Nigeria. Lett App Microbiol. 2013; 58(3): 262-269.

22. Al-Nabulsia AA, Osailia TM, Awada AA, Olaimatb AN, Shakera RR, Holley RA. Occurrence and antibiotic susceptibility of Listeria monocytogenes isolated from raw and processed meat products in Amman, Jordan. CYTA-J Food. 2015; 13(3): 346-352.

23. Food and Agriculture Organization. Quality assurance for microbiology in feed analysis laboratories, by R.A. Cowie. Edited by Harinder P.S. Makkar. FAO Animal Production and Health Manual No. 16. Rome. 2013.

24. Ieren II, Bello M, Kwaga JKP. Occurrence and antibiotic resistance profile of Listeria 
monocytogenes in salad vegetables and vegetable salads sold in Zaria, Nigeria. Afr J Food Sci. 2013; 7(9): 334-338.

25. Clinical and Laboratory Standards Institute. Performance Standards for Antimicrobial Susceptibility Testing; Twenty-Fourth Informational Supplement. CLSI document M100-S24. Wayne, PA. 2014.

26. Yakubu Y, Salihu MD, Faleke OO, Abubakar MB, Junaidu AU, Magaji AA, Gulumbe ML, Aliyu RM. Prevalence and antibiotic susceptibility of Listeria monocytogenes in raw milk from cattle herds within Sokoto Metropolis, Nigeria. Sokoto J Vet Sci. 2012; 10(2): 13-17.

27. Meti M, Govind V, Sundaresan G, Appa RV, Narendra BR. Isolation and detection of Listeria monocytogenes in chicken meat marketed in retail outlets by using simplex PCR. J Entomol Zool Stud. 2017; 5(5): 434-437.

28. Liu D, Busse HJ. Listeria. In: Liu D, editor. Molecular detection of food-borne pathogens. United Kingdom: CRC Press; 2009.

29. Islam MS, Husna AA, Islam MA, Khatun MM. Prevalence of Listeria monocytogenes in Beef, Chevon and Chicken in Bangladesh. Am J Food Sci Health. 2016; 2(4): 39-44.

30. Vermeulen A, Gysemans KPM, Bernaets K, Geeraerd Ah, Van Impe JF, Debevere J, Devlieghere $\mathrm{F}$. Influence of $\mathrm{pH}$, water activity and acetic acid concentration on Listeria monocytogenes at $7^{\circ} \mathrm{C}$ : data collection for the development of a growth/no growth model. Int J Food Microbiol. 2007; 114(3): 332-341.

31. Keeratipibul S, Techaruwichit P. Tracking sources of Listeria contamination in a cooked chicken meat factory by PCR-RAPD-based DNA fingerprinting. Food Control. 2012; 27(1): 64-72.

32. Kurpas M, Wieczorek K, Osek J. Ready-to-eat meat products as a source of Listeria monocytogenes. J Vet Res. 2018; 62(1): 49-55.
34. Ennaji $H$, Timinouni $M$, Ennaji $M$, Hassar $M$, Cohen N. Characterization and antibiotic susceptibility of Listeria monocytogenes isolated from poultry and red meat in Marocco. Infect Drug Resist. 2008; 1: 45-50.

34. Marius EC, Lorena AM, Tatiana VD, Alexandru $\mathrm{R}$, Alina MB. Antibiotic Susceptibility Profiles of Listeria monocytogenes strains isolated from food products and clinical samples. Rev Rom Med Lab. 2014; 22(2): 255-261.

35. Troxler R, von Graevenitz A, Funke G, Wiedemann B, Stock I. Natural antibiotic susceptibility of Listeria species: L. grayi, $L$. innocua, L. ivanovii, L. monocytogenes, $L$. seeligeri and $L$. welshimeri strains. Clin Microbiol Infect. 2000; 6(10): 525-535.

36. Hansen JM, Gerner-Smidt P, Bruun B. Antibiotic susceptibility of Listeria monocytogenes in Denmark, 1958-2001. APMIS. 2005; 113(1): 31-36.

37. Ramaswamy V, Cresence VM, Rejitha J, Mohandas UL, Dharsana KS, Suryaprasad PP, Helan MV. Listeria: Review of epidemiology and pathogensis. J Microbiol Immunol Infect. 2007; 40(1): 4-13.

38. Indrawattana $\mathrm{N}$, Nidabbhasobon $\mathrm{T}$, Sookrung $N$, Chongsa-Nguan $M$, Tungtrongchitr $A$, Makino S, Tungyong $W$, Chaicumpa $W$. Prevalence of Listeria monocytogenes in raw meats marketed in Bangkok and characterization of the isolates by phenotypic and molecular methods. J Health Popul Nutr. 2001; 29(1): 26-38.

39. Charpentier E, Courvalin P. Antibiotic resistance in Listeria spp. Antimicrob Agents Chemother. 1999; 43(9): 2103-2108. 